\title{
POTENSI POHON PENGHASIL GAHARU BUDIDAYA DI KABUPATEN KAMPAR PROVINSI RIAU
}

\author{
Sri Rahayu Prastyaningsih', Ervayenri ${ }^{1}$ dan Azwin ${ }^{1}$
}

\author{
${ }^{1}$ Staf pengajar Fakultas Kehutanan Universitas Lancang Kuning \\ Jln. Yos Sudarso Km. 8 Rumbai Pekanbaru Riau \\ Telp./Fax. (0761) 54092
}

Email: srirahayu_pn@yahoo.co.id, ervayenri2014@gmail.com, azwin@unilak.ac.id

\begin{abstract}
Scarcity of agarwood trees in natural forests cause agarwood trade of all species be included Aquilaria malacensis into CITIES (Convention on International trade in Endangered Species of Wild Fauna and Flora) and limited exsport quota. Agarwood is a resinous wood and has the benefit of such ingredients as perfumes and medicines. High economic value of Eaglewood cause increased community interest for cultivation of Gaharu plants

This research was done in January to March 2015 in Pangkalan Baru, Siak Hulu subdistrict and Kuapan, Tambang subdistrict, Kampar district, Riau Province. The materials used were map, related research, camera, GPS, compass, altimeter, measuring tape, hagameter, talysheet, etc. Field of observations with searching information about cropping in cultivation of agarwood, identification of farmers and cropping patterns. Survey of agarwood tree conducted by purposive sampling method. Data obtained by making a plot with measuring $20 \times 20$ m plated on transect with sampling intensity by $20 \%$.

The results of research on cropping pattern was monoculture and multiculture. Multiculture was in the rubber plants. The age of agarwood trees in monokultur was 19 years old., whereas multiculture between 2-5 tahun. Potential agarwood trees in monocultural was $19 \mathrm{~m}^{3}$ but multicultue can not be due to plant cause age $>5$ years.
\end{abstract}

Keywords : agarwood, cultivation of gaharu plants, kampar district 


\section{PENDAHULUAN}

Gaharu di Indonesia mulai dikenal masyarakat pada sekitar tahun 1200. Perdagangan antara masyarakat Sumatera Selatan dan Kalimantan Barat dengan Pedagang China, Kwang Tung (Sumarna, 2009). Pada saat itu, gaharu digunakan sebagai bahan pengharum tubuh dan ruangan dengan cara dibakar. Masyarakat yang beragama Hindu menggunakan gaharu sebagai bahan pelengkap ritual keagamaan. Secara tradisional masyarakat Papua telah menggunakan daun, kulit dan akar gaharu sebagai obat malaria dan perawatan kulit (Sumarna, 2002). Gaharu dimanfaatkan sebagai bahan obat untuk penghilang stress, gangguan ginjal, sakit perut, asma, hepatitis, pembengkakan liver dan limpa, antibiotika untuk TBC, reumatik, kanker, malaria serta radang lambung. Menurut Jiang et al, pada tahun1918-1925 berupa
(2011) gaharu merupakan antibakteri, antiinflamasi, analgesia dan antitumor.

Gaharu terbentuk pada jaringan kayu pohon penghasil dengan mekanisme dan proses biologis sebagai akibat adanya perlukaan alami pada batang atau cabang kemudian terinfeksi pada bagian yang luka oleh mikroba yang menimbulkan adanya penyakit. Tanaman akan melakukan pertahanan dari gangguan penyakit dengan membentuk antibodi. Pada kondisi tanaman yang mampu melindungi diri dari gangguan penyakit maka pohon tidak akan menghasilkan gaharu, sedangkan pada pohonpohon yang lemah terhadap serangan penyakit maka hara dari jaringan sel-sel kayu akan diubah menjadi senyawa fitoaleksin yang berupa resin gaharu berwarna coklat dan beraroma harum.

Perdagangan gaharu 
bahan mentah dengan volume sekitar 11 ton/tahun. Selanjutnya tahun 1983 -1987, sekitar 103 ton/tahun setara US $\$ 311.000$, tahun 1990 -1998 mencapai 165 ton/tahun setara US \$2 juta (Sumarna, 2009). Sejak tahun 2003, kuota ekspor gaharu menurun terus menjadi sekitar 125 ton/tahun untuk setiap species. Kelangkaan pohon gaharu di hutan alam menyebabkan perdagangan gaharu asal semua species Aquilaria dan Gyrinops di atur dalam CITES (Convention on International trade in Endangered Species of Wild Fauna and Flora), dan ekspornya dibatasi dalam kuota.

Kawasan lindung seperti Bukit Betabuh, Hutan Lindung Sentajo, Taman Nasional Tesso Nilo, Taman Nasional Bukit Tigapuluh, Hutan Lindung Bukit Rimbang, Bukit Baling, Bukit Bungkuk, Kerumutan, Bukit
Betabuh. Bukit Suligi dan Kuala Kampar merupakan daerah atau wilayah penghasil gaharu alam di Provinsi Riau (Balitbang, 2014). Masyarakat sekitar hutan mengumpulkan gaharu dalam kelompok yang terdiri dari beberapa orang. Mereka tinggal di hutan selama kurang lebih seminggu untuk mencari gaharu di dalam hutan. Tetapi seiring dengan potensi yang semakin menurun maka mereka tinggal di hutan lebih dari 2 minggu bahkan sebulan hanya untuk mendapatkan gaharu (Setyawati, 2014) sehingga mencari gaharu di hutan merupakan hal yang tidak menarik lagi karena ketidakpastian dan waktu yang lama untuk mendapatkan gaharu alam.

Budidaya tanaman gaharu di Indonesia sudah dimulai sejak tahun 1990 bahkan masyarakat menanam di lahan-lahan miliknya sendiri sebagai investasi jangka 
panjang. Tingginya harga gaharu di pasaran menyebabkan masyarakat tertarik untuk mengusahakan jenis tanaman penghasil gaharu dengan harapan kelak akan mendapatkan keuntungan yang besar. Pengembangan tanaman penghasil gaharu jenisAquilaria malacensis Lamk sudah dilaksanakan di berbagai kabupaten di Provinsi Riau. Kabupaten Kampar merupakan salah satu kabupaten yang memiliki potensi yang cukup besarmengingat masyarakat yang tertarik membudidayakan Aquailaria malacensis Lamk sebagai penghasil gaharu dengan harapan kelak akan mendapatkan keuntungan yang besar.

Dari hasil survey lapangan di Kabupaten Kampar terdapat tegakan Aquailaria malacensis Lamk yang diusahakan oleh2 (dua) kelompok Tani gaharu yaitu
Kelompok Tani Riau Sembada dan Kelompok Masyarakat Gaharu dengan luas tanam bervariasi antara 1- 5 hektar yang tersebar di 2 (dua) kecamatan yaitu kecamatan Siak Hulu dan kecamatan Tambang (Balitbang, 2014). Pengembangan pohon penghasil gaharu yang dikelola oleh masyarakat di desa Pangkalan Baru, Kecamatan Siak Hulu ditanam secara monokultur, sedangkan di Kecamatan Tambang adalah pola multikultur atau ditanam di antara pohon karet. Pola tanam akan mempengaruhi potensi tegakan pohon penghasil gaharu sehingga informasi mengenai hal tersebut akan sangat membantu dalam pengelolaan tegakan selanjutnya. Sehubungan dengan hal tersebut maka dapat dirumuskan dalam bentuk pertanyaan yang menjadi kajian penelitian ini yaitu : 
(1) Bagaimana pola tanam yang dilakukan terhadap tegakan pohon penghasil gaharu?

(2) Seberapa besar potensi pohon penghasil gaharu yang ada di kedua lokasi tegakan tersebut?

\section{METODE}

Penelitian

ini

dilaksanakan di desa Pangkalan Baru, Kecamatan Siak Hulu dan Desa Kuapan Kecamatan Tambang, Kabupaten Kampar, Provinsi Riau. Pelaksanaan penelitian dimulai pada bulan Januari 2015 sampai dengan bulan Maret 2015.

Bahan dan alat dalam penelitian ini adalah :

1. Peta wilayah Kabupaten Kampar.

2. Laporan hasil penelitian yang terkait dengan penelitian yanng akan dilaksanakan.

3. Kamera untuk dokumentasi.

4. Peralatan inventarisasi hutan (GPS, kompas, altimeter, pita ukur, hagameter, talysheet, peralatan tulis dII).

Observasi lapangan dilakukan untuk memperoleh informasi mengenai kegiatan pengelolaan budidaya pohon penghasil Gaharu jenis Aquilaria malacensis Lamk yaitu identifikasi petani, luas lahan dan pola tanam.

Kegiatan survey pohon penghasil gaharu jenis Aquilaria malacensis Lamk dilakukan dengan metode purposif sampling. Potensi tegakan diperoleh dengan membuat plot ukuran 20 × $20 \mathrm{~m}$ yang disebar pada pola jalur/transek dengan intensitas sampling sebesar $20 \%$.

Perhitungan potensi pohon penghasil gaharu jenis Aquilaria malacensis Lamk ditentukan dengan rumus :

$$
V=1 / 4 . \pi \cdot d^{2} . t . f
$$

Keterangan :

$\mathrm{V}=$ volume $\left(\mathrm{m}^{3}\right)$

$\mathrm{d}=\operatorname{diameter}(\mathrm{m})$ 
$\mathrm{t}=$ tinggi bebas cabang $(\mathrm{m})$

$f$ = angka bentuk $(0,6)$

$\pi=3,14$

\section{HASIL DAN PEMBAHASAN}

\section{POLA TANAM GAHARU}

(Aquilaria malacensis Lamk) Kabupaten Kampar memiliki potensi yang cukup besar dalam budidaya gaharu. Pembudidayaan gaharu di Kabupaten Kampar diawali dari adanya kegiatan yang dilakukan oleh Dinas Kehutanan Provinsi Riau yaitu "Pencanangan Penanaman Satu Miliar Pohon Gaharu" yang dipusatkan di lahan milik kelompok tani dan mitra yang bergabung di dalamnya dengan luas ratusan hektar. Pencanangan penanaman pohon ini dilakukan dengan penyerahan bibit beberapa pohon jenis gaharu dan lainnya oleh Kepala Dinas Kehutanan Provinsi Riau kepada kelompok-kelompok tani dari beberapa kecamatan dan beberapa kabupaten di Provinsi Riau yang hadir dalam kegiatan tersebut (Balitbang, 2014). Pengembangan tanaman gaharu di Kabupaten Kampar dilakukan di lahan milik masyarakat oleh masyarakat dengan pola tanam monokultur maupun multikultur.

Dari data sekunder (Balitbang, 2014), diambil 2 (dua) lokasi yang dikelola oleh 2 (dua) kelompok tani yaitu Kelompok Masyarakat Gaharu, Desa Kuapan, Kecamatan Tambangdan Kelompok Tani Riau Sembada, Desa Pangkalan Baru, Kecamatan Siak Hulu.

Tanaman gaharu budidaya yang ditanam secara monokultur berlokasi di Desa Pangkalan Baru, Kecamatan Siak Hulu, Kabupaten Kampar. Tanaman gaharu sudah ditanam sejak tahun 1997 dengan jarak tanam $3 \times 3$ meter. Jarak tanam yang terlalu rapat menghasilkan jumlah tanaman 
yang cukup banyak tetapi milik masyarakat yang ada. Selain mempengaruhi diamater batang. dari bantuan bibit dari pemerintah, Dari hasil pengamatan di pengadaan bibit dan lapangan, terdapat variasi pemeliharaan tanaman juga pertumbuhan pohon gaharu yang berasal dari mitra kerjasama disebabkan oleh tanaman (perusahaan swasta) dalam sulaman pada saat pemeliharaan. bentuk kredit yang dibayarkan jika Pengembangan tanaman tanaman gaharu sudah gaharu disela-sela tanaman semusim maupun tanaman menghasilkan.

Pada awal pertumbuhan tahunan dikenal dengan pola pada umur 3 bulan sampai 1 multikultur. Di Desa Kuapan, tahun, tanaman gaharu bersifat Kecamatan Tambang, gaharu semi toleran atau memerlukan ditanam secara multikultur naungan. Pertumbuhan tanaman ditanam disela-sela tanaman karet (Balitbang, 2014) dengan umur $\geq$ 5 tahun. Dengan luas lahan masyarakat yang tidak begitu luas yaitu $\geq 5$ ha, tanaman gaharu ditanam disela-sela pada lahan yang sudah ditanami oleh jenis tanaman lainnya seperti karet, sawit, kakao dan tanaman hutan lainnya. Jarak tanam bervariasi karena jumlah tanaman gaharu yang ditanam disesuaikan dengan kondisi areal lahan atau hutan gaharu yang berumur 9 bulan dibawah tegakan tanaman kakao mempunyai pertumbuhan yang cukup baik. Tanaman gaharu yang dibudidayakan di lahan karet mencapai tinggi 3,0 $\mathrm{m}$ dan diameter batang $4,3 \mathrm{~cm}$ pada umur tiga tahun. Suhartati(2011) menyatakan bahwa tanaman gaharu yang dibudidayakan di lahan hutan rakyat mencapai pertumbuhan tinggi $4,8 \mathrm{~m}$ dan diameter batang $7,1 \mathrm{~cm}$ pada 
umur empat tahun. Selain faktor cahaya, jarak tanam menjadi hal yang sangat penting bagi pertumbuhan tanaman karena adanya kompetisi unsur hara dengan tanaman lainnya. Jarak tanam gaharu yanng ditanam di sela-sela tanaman karet adalah 5 x 3 meter, sedangkan di kawasan hutan adalah $6 \times 8$ meter dengan jarak tidak beraturan. Budidaya gaharu idealnya dilaksanakan dengan pola multikultur dengan tanaman pokok berumur $5 \geq$ tahun karena pada umur demikian tanaman pokok sudah dapat menjadi naungan bagi tanaman gaharu.

\section{POTENSI POHON PENGHASIL GAHARU}

Pengukuran potensi gaharu dengan pola tanam monokultur dilakukan di Desa Pangkalan Baru, Kecamatan Siak Hulu, Kabupaten Kampar dengan cara mengukur diameter dan tinggi bebas cabang. Dari pohon sampel yang diukur diperoleh rata-rata pertumbuhan tinggi dan diameter.Hasil pengukuran tinggi (m) dan diameter (cm) dapat dilihat pada gambar berikut :

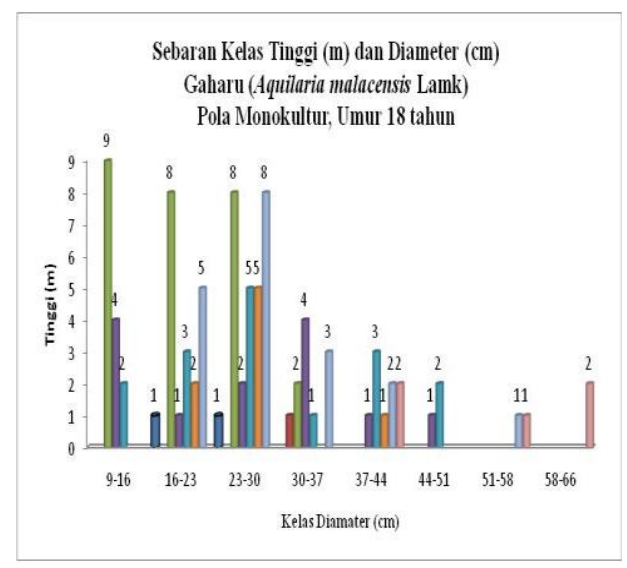

Gambar 2. Sebaran kelas tinggi (m) dan diameter $(\mathrm{cm})$ tanaman gaharu (Aquilaria malacensis Lamk) pola monokultur, umur 18 tahun.

Rata-rata pengukuran tinggi $(\mathrm{m})$ antara $1 \mathrm{sd} 9 \mathrm{~m}$ dengan rata-rata adalah 5,8 $\pm 1,8 \mathrm{~m}$, sedangkan diameter $(\mathrm{cm})$ antara 9 sd $60 \mathrm{~cm}$ dengan rata-rata 27,74 \pm $11,6 \mathrm{~cm}$. Dari hasil pengamatan menunjukkan bahwa terdapat variasi pertumbuhan Aquilaria malacensis Lamk (Prastyaningsih, 2014). Gaharu jenis Aquilaria 
malacensis Lamk sudah ditanam sejak 1997 (umur \pm 18 tahun), tetapi pertumbuhannya kurang seragam. Beberapa lokasi dijumpai anakan gaharu dengan umur $\geq 5$ tahun yang merupakan sulaman dari tanaman gaharu yang telah mati dan beberapa tempat dibiarkan kosong.

Gubal gaharu yang terbentuk dapat melalui proses infeksi cendawan secara alami atau dapat dilakukan melalui penyuntikan. Jenis jamur yang dikembangkan antara lain Fusarium sp ke tanaman gaharu yang sudah berumur $\geq 5$ tahun atau diameter batang $\geq 15 \mathrm{~cm}$ (Mucharomah, 2010 dalam Iskandar, 2013). Terbentuknya gaharu, selain daripada jenis jamur yang digunakan juga oleh pohon penghasilnya. Potensi kayu yang besar yang didukung dengan inokulan akan menghasilkan luasan infeksi yang dihasilkan sehingga penghitungan potensi kayu gaharu perlu dilakukan. Perhitungan potensi gaharu (Aquilaria malacensis Lamk) pola monokultur di Desa Pangkalan Baru, Kecamatan Siak Hulu, Kabupaten Kampar rata-rata adalah $19 \mathrm{~m}^{3} /$ hadengan potensi pohon terkecil adalah $0,02 \mathrm{~m}^{3} / \mathrm{ha}$ dan terbesar $0,85 \quad \mathrm{~m}^{3} / \mathrm{ha}$ (Prastyaningsih, 2014). Jarak tanam gaharu monokultur adalah $3 \times 3$ meter, sementara jarak ideal adalah $5 \times 5$ meter. Potensi ini juga dipengaruhi oleh bentuk batang pohon gaharu. Sebagian besar pohon dijumpai batang pokok lebih dari satu yaitu sekitar satu sampai lima pokok. Potensi hanya dihitung berdasarkan batang pokok yang paling besar. Di satu sisi, bentuk batang yang demikian dapat mengatur kesinambungan produksi gaharu karena dapat dipilih satu batang sementara batang yang lain dapat disuntik pada waktu yang sama 
dengan pemanenan yang berbeda.

Pada pola tanam multikultur di Desa Kuapan, Kecamatan Tambang, Kabupaten Kampar tidak dilakukan mengingat umur tanaman $\geq 5$ tahun.Tanaman gaharu umur $\geq 5$ tahun, dbh mencapai 6,3-7,62 cm dan tinggi $\geq 6 \mathrm{~m}$. (Wiriadinata, 2010). Di Riau, pada umur $\geq 10$ tahun pohon gaharu budidaya baru mencapai ukuran 13.77 - 19, $85 \mathrm{~cm}$ (Semiadi, 2009) .

\section{KESIMPULAN}

1. Terdapat 2 bentuk pengembangan tanaman gaharu(Aquilaria malacensis Lamk) di Kabupaten Kampar yaitu pola tanam multikultur dan monokultur.

2. Pola tanam multikultur yaitu tanaman gaharu (Aquilaria malacensis Lamk) ditanam disela-sela tananan karet dan atau tanaman hutan.
3. Gaharu (Aquilaria malacensis Lamk)yang ditanam dengan pola multikultur adalah 2 sd 5 tahun, sedangkan gaharu yang ditanam dengan pola monokultur berumur 18 tahun.

4. Potensi tanaman gaharu (Aquilaria malacensis Lamk) pola monokultur adalah 19 $\mathrm{m}^{3} / \mathrm{ha}$.

5. Terdapat 2 bentuk pengembangan tanaman gaharu(Aquilaria malacensis Lamk) di Kabupaten Kampar yaitu pola tanam multikultur dan monokultur.

6. Pola tanam multikultur yaitu tanaman gaharu (Aquilaria malacensis Lamk) ditanam disela-sela tananan karet dan atau tanaman hutan.

7. Gaharu (Aquilaria malacensis Lamk)yang ditanam dengan pola multikultur adalah 2 sd 5 tahun, sedangkan gaharu yang ditanam dengan pola monokultur berumur 18 tahun. 
8. Potensi tanaman gaharu (Aquilaria malacensis Lamk) pola monokultur adalah 19 $\mathrm{m}^{3} / \mathrm{ha}$.

\section{SARAN}

1. Potensi tanaman gaharu multikultur dapat dihitung setelah umur tanaman $\geq 5$ tahun.

2. Penyuntikan bisa dilakukan pada tanaman gaharu monokultur mengingat umurnya $\geq 18$ tahun dengan seleksi diameter batang $\geq 16$ $\mathrm{cm}$.

\section{DAFTAR PUSTAKA}

Argent $G$ et al. 1998. Manual of The larger and More Important Non Dipterocarp Trees of Central Kalimantan, Indonesia.Volume 2. Forest Research Institute Samarinda, Indonesia. 705 p.

Badan Litbang Kehutanan dan Perkebunan.(1998). Sinopsis hasil-hasil kehutanan. Jakarta.
Badan Litbang Kehutanan, 2014. Kajian Pohon Gaharu Dalam Mendukung Upaya Konservasi Dan Pelestarian Alam di Provinsi

Riau.Pekanbaru

Ding Hou. 1960. Thymelaeaceae. Flora Malesiana Series 1 Spermatophyta Volume 61 48.

Hadi AK, (2011). Sepuluh Tanaman Investasi Pendulang Rupiah. Penebar Swadaya.

Iriansyah M et al. 2006. Gaharu Komoditi Masa Depan Yang Menjanjikan. Balai Penelitian dan Pengembangan Kehutanan

Kalimantan.Samarinda.

Iskandar, Dudi dam Suhendra Ahmad. Inokulasi Fusarium sp untuk produksi gaharu pada budidaya $A$. Beccaricana. Jurnal Sains Teknologi Indonesia Volume 14 No 3 Desember 2013. Jakarta

Jiang, S. et al, 2011.Journal of Chinese Pharmaceutical Sciences, 609-614

Ponirin S. 2003. Budidaya Gaharu. Balai Penelitian dan Pengembangan Kehutanan. Departemen Kehutanan. Jakarta. 
Prastyaningsih, S.R (2011). Pertumbuhan Eucaliptus pellita di lahan Universitas Lancang Kuning. Jurnal Wahana Foresta Vol 4 No 1 hal 66-78. Fakultas Kehutanan. Universitas Lancang Kuning.

Prastyaningsih, (2014).Potensi

S.R Penghasil Gaharu jenis Aquilaria malacensis Lamk (Studi Kasus di Desa Pangkalan Baru, Kecamatan Siak Hulu, Kabupaten Kampar, Provinsi Riau). Jurnal Wahana Foresta Vol 8 No 2. hal 36-41. Fakultas Kehutanan. Universitas Lancang Kuning.

Semiadi G, H Wiriadinata,E.B, Waluyo dan D.Darnaedi. 2009. Budidaya Gaharu (Aquilaria spp) di Provinsi Riau.Alternatif, Solusi Berkelanjutan.Agrivita Journal.Submmitted

Setyawati, Titik. 2011. Potensi dan Kondisi Regenerasi Alam Gaharu (Aquilaria malacensis Lamk di Provinsi Lampung dan Bengkulu. Isi Buku Gaharu.https://ml.scribd.com/ doc/.../Isi-Buku-Gaharu-5Januari-2011-Full-Size.

Diakses 12 Desember 2014.
Susilo KA, (2003). Sudah Gaharu Super Pula. Pustaka Sinar Harapan. Jakarta

Soehartono T, Mardiastuti A. 2003. Pelaksanaan Konvensi CITESdi Indonesia.JICA. Jakarta.

Sofyan Agus, Sumadi Agus, Kurniawan Agus dan Nurlia Ari (2010). Pengembangan dan Peningkatan Produktifitas Pohon Penghasil Gaharu Sebagai Bahan Obat di Sumatera. Laporan Hasil Penelitian. Kementrian Kehutanan. Balai penelitian Kehutanan. Palembang.

Sumadiwangsa S, Zulneli. 1996. Laporan Perjalanan Dinas. Penelitian Gaharu di

Kalimantan Timur.Pusat Penelitian Hasil Hutan dan Sosial Ekonomi Kehutanan. Bogor.

Sumarna, Yana. (2002). Budidaya Gaharu. Seri Agribisnis. Jakarta. Penebar Swadaya.

Suharti, Sri, 2009. Prospek Permodalan

Gaharu.www.forda-

mof.org/files/04 Ni2k klm ok .pdf. Diakses 12 Desember 2014.

Suharti, Sri. 2014.Model Kemitraan Usaha Tani Gaharu Bersama Masyarakat.Tepian Hutan. 
www.forda-

mof.org/index.php/berita/post/ 1722. Diakses 12 Desember 2014.
Suharti, Sri.2009. Prospek Pengusahaan Gaharu Melalui Pola Pengelolaan Hutan Berbasis Masyarakat (PHBM).Pusat Litbang dan Konservasi Alam. Bogor 